\title{
Analysis of the Key Technologies in Roof Waterproof Design and Construction of High Rise Building
}

\author{
Xianggang Kong \\ Department of Civil Engineering, Guangxi Polytechnic of Construction, Nanning, China
}

\begin{abstract}
In this paper, the present situation of roof waterproof technology was discussed and the working principle and failure reasons of roof waterproof system were analyzed. Combined with the actual high-rise building project, the key technologies of roof waterproofing design and construction have been discussed in detail.
\end{abstract}

Keywords-high rise building; roof waterproof; construction technology; inverted roof

\section{DEVELOPMENT OF ROOF WATERPROOF TECHNOLOGY}

Roof leakage is a common quality problem in building engineering, and it is a difficult problem that has not been solved well. In recent years, with the continuous development of computer, microelectronics technology, new energy and new materials, waterproof construction technology of building has become more scientific and reasonable, new waterproof material also shows a gradually diversified development trend.

Glass fiber reinforced cement (GRC) is a new material with high strength and light weight, which can effectively improve the crack resistance of concrete. Rigid polyurethane foam is a kind of building material with waterproof and thermal insulation function. In the United States and Italy, the main building waterproof materials using self-adhesive polymer modified asphalt waterproofing membrane and three ethylene propylene rubber membrane.

In recent years, the research and development of polyethylene polypropylene fiber composite waterproofing membrane performance is also very good, with strong impervious capacity, high tensile strength, low temperature flexibility, stability, non-toxic and other performance characteristics. For example, some spray polyurea elastomer spray has been developed by China National Institute of Oceanography. This kind of material has reached the world advanced level, which has the characteristics of wear resistance, high strength, corrosion resistance, ageing resistance and so on.

In the construction of roof waterproof technology, the transformation from single waterproof material to composite waterproofing of coil and film has been gradually realized in China. Rigid waterproof and flexible waterproof has been combined to achieve complementary advantages. In the past, the waterproof layer was arranged above the insulation layer. But now, the waterproof layer is arranged below the insulation layer. This new roof is generally known as the inverted roof. In the construction of waterproof coating, how to speed up the film curing speed and control the film thickness becomes the key technology. In membrane joint construction, there are some new technologies such as hot melt method, hot air welding and heat welding method.

\section{ROOF WATERPROOFING TECHNOLOGY}

At present, the waterproof technology adopts the principle of rigid and flexible combination, compound waterproof, multiple defense and integral sealing.

\section{A. Rigid Waterproof}

Waterproof concrete, waterproof mortar and steel plate, rigid plastic plate and so on is the rigid waterproof layer. Waterproof concrete has good durability, low cost, simple construction, reliable quality and other advantages. It can be used for load-bearing and waterproof, so waterproof concrete becomes the first choice of rigid waterproof material. In the construction of waterproof concrete, the solid area of cement mortar will increase by $20 \%$ and the volume of concrete will expand, which will lead to the densification of its own structure. The capillary channels in concrete and the harmful holes greater than $200 \times 10-8 \mathrm{~cm}$ will be filled by C-S-H gel produced during cement hydration and $\mathrm{A} 1(\mathrm{OH}) 3$ gel produced by the addition of aluminum sulfate to the water proofing agent. After compaction, light, adequate heat and moisture curing, the concrete will have good impermeability.

\section{B. Flexible Waterproof}

Flexible waterproof materials generally include modified asphalt membrane, polymer membrane and coating material containing the above material. These materials generally have three characteristics. First of all, the components of the material are hydrophilic and hydrophobic. Second, there is a continuous film on the surface of the material, so water is difficult to penetrate directly. Third, the molecular chain of EPDM has good chemical stability, UV resistance, better light thermal effect, good temperature adaptability and long service life.

\section{Multi-defense and Overall Tightness}

With the guideline of multi-defense, the composite waterproof layer is formed by the flexible waterproof layer and rigid waterproof layer. Aiming at the leakage site, such as the end of waterproof layer, the movement joint of roof, the dividing joint of leveling blanket, entrance, cornice, the root of parapet, the root of funnel, the root of piping and the root of equipment, the flexible sealing material, waterproof coating or membrane are combined together to form a local reinforcing additional layer. With the help of organic or inorganic adhesive 
material, a watertight system is formed between the multiple defenses.

\section{FAILURE ANALYSIS OF ROOF WATERPROOFING}

Waterproof design, waterproof materials and waterproof construction quality level are the main factors leading to the failure of roof waterproof. The survey data on the causes of roof leakage are listed in Table 1.

TABLE I. ANALYSIS DATA OF ROOF LEAKAGE

\begin{tabular}{|l|c|c|}
\hline \multirow{2}{*}{$\begin{array}{c}\text { Investigation } \\
\text { project }\end{array}$} & $\begin{array}{c}|c| \\
\text { Investigation unit } \\
\text { American Academy of } \\
\text { Building Research }\end{array}$ & $\begin{array}{c}\text { China Building Technology } \\
\text { Development Center }\end{array}$ \\
\hline Design & 58 & 26 \\
\hline Construction & 35 & 48 \\
\hline Material & 12 & 20 \\
\hline Maintenance & $/$ & 6 \\
\hline Other & 13 & $/$ \\
\hline
\end{tabular}

\section{A. Design Reasons}

In the process of design, there are three main causes of roof leakage. First, some settlement joint are set improperly. Second, the improper treatment of foundation or unreasonable design leads to uneven settlement of buildings. Third, the unreasonable design of the structure leads to the cracking of roof waterproof layer caused by thermal stress.

\section{B. Causes of Construction}

There are three main reasons for the roof leakage due to construction problems. One is the concrete proportion of rigid waterproof layer is inappropriate or improper maintenance. The other is that a working layer with high moisture content lead to the bond strength of flexible waterproof membrane is not enough, hollowing and peeling. The last one is that the irregular construction of membrane lead to the lap seam is too narrow or the seal is not tight.

\section{Causes of Quality Management}

There are 4 reasons for the roof leakage caused by improper quality control. The first reason is that shoddy waterproofing materials are used. Second, nonprofessional construction team undertake the project. Third, construction management is not appropriate and protection measures are not in place.

Therefore, the roof waterproof is a systematic project. Design standardization, standardization of materials and construction process specialization should be fully implemented in order to truly achieve the goal of "no leakage".

\section{Key POINTS OF ROOF WATERPROOF DESIGN}

The key of waterproof design is how to make waterproof structure scientific and reasonable. At the same time, it is necessary to strengthen the quality control of parts at which leakage is easy to appear. In waterproof design, the following key points should be taken seriously.

\section{A. Combination of Function and Cost}

At present, the roof of residential buildings is divided into flat roof and sloping roof. The waterproof structure is generally composed of the structural layer, slope layer, leveling layer, vapor barrier layer, thermal insulation layer, waterproof layer, protective layer, decorative layer, etc. From the view of the roof structure, the roof should have many functions, such as bearing, waterproof, heat preservation and heat insulation. It should be said that these structural levels are set around the waterproof layer. Therefore, in the roof engineering, waterproof function should be the primary goal to be met. According to the principle of value engineering, combined with the characteristics of building waterproof engineering, the function-cost comprehensive evaluation method has be used in the roof engineering design. Through the comprehensive comparison between the function score and the cost valuation, the function-cost comprehensive evaluation method is a good design method for selecting the waterproof structure.

\section{B. Adapt to the Environment}

China has a vast territory. The climate conditions vary widely and the level of economic development between regions is also inconsistent. Therefore, when the waterproof structure is designed, the water level, the service life of the waterproof layer, the climate and the economic conditions of the region should be considered synthetically.

\section{The Structural Levels Match Each Other}

In the process of roof engineering design, the thermal insulation material should be placed on the outside of the roof and the waterproof layer should be placed on the inside. In this way, the roof could have the best thermal effect without leakage.

\section{Environmental Benefits and Sustainable Development}

The roof is not only the fifth elevation of the building, but also another scenic line of the city. Therefore, the roofing waterproofing design must be taken into account in the urban planning in order to reflect the characteristics of different regions and different cities.

\section{Key TECHNOLOGIES OF ROOF WATERPROOF CONSTRUCTION}

Roof waterproof engineering construction is a process with high technical requirement and high standard requirements. In the construction, many key technologies need to be paid special attention to.

\section{A. Key Technologies in the Main Construction Stage}

The waterproof engineering is a systematic project, so measures must be taken to form multi points of protection in the main construction stage. The strength of concrete, mix proportion, slump and the thickness of reinforced protective layer should be ensured to meet the design requirements. In the process of construction, the roof concrete should be vibrated mechanically to avoid cold cracks. The sack should be placed on the roof to protect the concrete in order to ensure that the concrete surface does not crack. Construction joints cannot be 
set in the peripheral vertical structure and the bottom of the joints must be cleaned up before construction.

\section{B. Climatic Conditions of Roof Waterproof Layer Construction}

The construction condition is directly related to the construction quality and the waterproof construction is greatly affected by climatic factors. During the construction period, rain, snow, frost, fog, wind and temperature below 5 degrees or above the temperature of 35 degrees will hinder the construction. Hot melt type membrane and solvent-borne coatings can be laid at temperatures above -10 degrees. When the temperature is below 0 degrees, asphalt, modified asphalt and high polymer membrane should not be constructed. When the temperature is below 5 degrees, asphalt based coating and high polymer emulsion coating and rigid waterproof layer should not be constructed. When the temperature exceeds 35 degrees, all waterproof layer construction should be stopped.

\section{Pay Attention to the Construction Crossing Problems}

The leveling layer, vapor barrier layer, thermal insulation layer, waterproof layer and protective layer are all related to the construction of waterproof layer. The construction of these related layers often cross each other. These crossing constructions have a great impact on the quality of the waterproof layer. Therefore, special attention should be paid to the construction of protective layer and waterproof layer cannot be destroyed.

\section{Key Technical Points of Rigid Waterproof Layer Construction}

1) According to the design requirements, the concrete mix proportion, water cement ratio and the amount of fly ash or mineral powder in the concrete are strictly controlled.

2) When the pumping concrete is used, the water used to wash the pump must be treated to avoid the structural weaknesses. If the area is not large, tower crane can be used to cast concrete.

3) After construction, concrete must be timely and effectively maintained and the concrete of structure must be maintained for more than 15 days in order to ensure that the capillary channel could be filled with C-S-H, A1 (OH) 3 and $\mathrm{Fe}(\mathrm{OH})_{3}$ gel.

4) Civilized construction is necessary. Roof load cannot be applied prematurely and excessive load should be prohibited to avoid structural cracks.

5) Rebar should be arranged reasonably and the double layer reinforcing mesh should be kept strictly separation. In the process of pouring concrete, the material should not be piled too high. Before the strength of concrete reaches M5, it is strictly forbidden to trample.

6) Some pipes or tubes are designed to extend out of the roof, the surrounding concrete of these parts and the concrete of roof structure should be placed at the same time in order to avoid the leakage caused by roof ponding.

7) The result of close water test must be qualified before the construction of flexible waterproof layer.

\section{E. Selection of Flexible Waterproofing System}

In the selection of the appropriate flexible waterproof material, the environment temperature, humidity, rainfall, the function of the building, waterproof design level, the actual construction conditions and other factors should be considered. The low temperature performance of SBS membrane is better, so it is more suitable for the area with low temperature. The high temperature performance of APP membrane is good, so it is often used in the region with high temperature or strong solar radiation. The polyethylene rubber membrane is suitable for the buildings with high waterproof grade. However, if a sloping roof has a larger slope, the linoleum tile or the ceramic will be the suitable materials and waterproof and decorative effect is good.

\section{ENGINEERING EXAMPLE}

In Nanning, some higher vocational college has built three high-rise residential buildings with 32 floors. In the process of construction, a number of key waterproof technologies mentioned in this paper have been successfully applied and waterproof effect of the roof is good. Their specific practices are listed below:

1) The roof waterproof adopts the inverted roof assembled with the flexible waterproof and rigid waterproof.

2) During the construction process of rigid waterproof layer, the steel fiber reinforced concrete is used to improve the crack resistance of the roof.

3) After the presence of surface crack of concrete, within the range of $500 \mathrm{~mm}$ around cracks, the impermeable concrete was poured again.

4) The PVC membrane was selected to build flexible waterproof layer. The construction technology of mechanical fixation and hot air welding was adopted. Additional layer was set in all of external corner, internal corner, parapet, scupper, pipe and other parts. The right angles of the upper and lower layers were cut into rounded corners and all seams were sealed with sealant. Below the support point of the lightning rod, the double layer method is adopted to avoid the damage of the waterproof system caused by the long-term wear.

\section{CONCLUSIONS}

It is proved by engineering application that the inverted roof which is composed with PVC flexible membrane and steel fiber reinforced concrete rigid layer is a kind of safe and effective roof waterproofing technology.

\section{ACKNOWLEDGMENT}

Thanks to the Guangxi Construction Engineering Group NO.2 installation Construction CO., Ltd to provide relevant project information. Thanks to the Guangxi golden umbrella waterproof Co., Ltd to provide waterproof material.

\section{REFERENCES}

[1] LIU Liming, MAO Jize, LYU Jianfu, LI Ben, GUO Qingyong. Effects of ambient humidityon mechanical properties of glass fiber reinforced cement. Acta Materiae Compositae Sinica. 2015, 33(5), pp.1072-1077. 
[2] ZHU Jun. Application of Rigid Polyurethane Foam in Building Energy Efficiency. China Plastics Industry. 2016, 44(5), pp.15-17.

[3] HUANG Lin, DING Hui. Discussion and Study on Solvent Content Testing Method for Polymer Modified Self-adhesive Bituminous Waterproofing Membrane. China Building Waterproofing. 2017(6), pp.38-42.

[4] WANG Hong. Leakage Prevention Management of Flexible Waterproof Roof. Construction Technology. 2007, 36(7), pp.139-140.

[5] SHEN Chunlin. Waterproof design and construction manual for building engineering. Beijing: China Electric Power Press, 2011.

[6] ZHANG Tong, FANG Jing, ZHOU Yuanlin. The Analysis and Strategy of Crux and Difficulty About Constructional Waterproof Technology. Industrial Construction, 2005(35) , pp.673-676.

[7] SHEN Chunlin. Construction method of new waterproof material. Beijing: China Building Industry Press, 2013. 